\title{
Pengaruh Non-Debt Tax Shield Dan Cost Of Financial Distress Terhadap Struktur Modal Pada Perusahaan Sub Sektor Logam Dan Sejenisnya Yang Terdaftar Di Bursa Efek Indonesia (BEI) Tahun 2013-2017
}

\author{
${ }^{1}$ Muhammad Yusuf, ${ }^{2}$ Andika Kurniawan \\ ${ }^{1,2}$ Institut Ilmu Sosial Dan Manajemen STIAMI \\ 1 yoezoef_sukses@yahoo.com ; ${ }^{2}$ andikakurniawan369@gmail.com
}

\section{ARTICLE INFO}

Keywords

non-debt tax shield, cost of financial distress, capital structure

\begin{abstract}
This research aims to provide the influence of non-debt variable tax shield and cost of financial distress affect the capital structure of the company's sub-sector metals and the like listed on the Indonesia Stock Exchange in 2013-2017.

The method on this research is a quantitative approach with the type of correlation study.

The data collection techniques in this study use secondary data with saturated sampling techniques. The population of this research is a metal sub-sector company and the like listed on the Indonesia Stock Exchange (IDX). The samples in this study were as many as 16 metal sub-sector companies and the like listed on the Indonesia Stock Exchange (IDX).

The results showed that both the partial and simultaneous variables of the non-debt tax shield and cost of financial distress had no effect on the capital structure of the metal sub-sector companies and the like listed on the Indonesia Stock Exchange ( IDX). It shows that the T-Test in a non-debt tax shield variable is obtained by the T-calculate result of 1.401 and the value of Sig. T. Acquired by 0, $165>0.05$, then Ho accepted and H1 rejected which means there is no positive influence on the capital structure and in variable cost of financial distress obtained with the result of T-Calculate of 1.756 and the value of Sig. T. Acquired by 0, $083>0.05$, then Ho is accepted and $\mathrm{HI}$ is rejected which means there is no positive influence on the capital structure. Then simultaneously $F$ test result in can with a fcalculate value of 2.295 with a level of Sig. 0, 108, because of the value of Sig. F> 0.05, then Ho accepted and $H 1$ rejected. This means that there is no variable influence of non debt tax shield (X1) and cost of financial distress (X2) to the capital structure (Y).
\end{abstract}

\section{PENDAHULUAN}

Perusahaan merupakan salah satu sarana yang dapat menunjang program pemerintah di berbagai sektor perekonomian. Seiring dengan perkembangan dunia usaha yang semakin pesat ini akan membawa dampak persaingan perdagangan yang ketat, terutama pada perusahaan sejenis. sehingga, perusahaan dituntut bekerja lebih efisien supaya perusahaan dapat bertahan hidup. Dengan demikian, perusahaan harus memperbaiki atau meningkatkan beberapa faktor, yaitu ketepatan waktu, kualitas, dan modal.

Kebutuhan akan modal sangat penting dalam membangun dan menjamin kelangsungan perusahaan selain faktor pendukung lainnya. Perusahaan membutuhkan modal dalam melakukan kegiatan usahanya yang digunakan untuk membiayai kegiatan operasional perusahaan sehingga dapat hidup dan terus berkembang dari tahun ke tahun. Modal yang digunakan perusahaan, yakni modal sendiri (equity) dan hutang (debt) baik hutang jangka pendek maupun hutang jangka panjang. Hutang jangka pendek sering disebut hutang lancar, yaitu kewajiban yang harus dipenuhi dalam jangka waktu kurang dari satu tahun atau dalam jangka siklus bisnis perusahaan, selain itu hutang jangka panjang merupakan kewajiban yang harus dipenuhi dalam jangka waktu lebih dari satu tahun. 
Perusahaan manufaktur adalah suatu perusahaan yang aktivitasnya mengelola bahan mentah atau bahan baku sehingga menjadi barang jadi lalu menjualnya kepada konsumen. Umumnya kegiatan seperti ini sering disebut dengan proses produksi. Industri manufaktur merupakan salah satu primary sector di Bursa Efek Indonesia sehingga industri ini lebih mencerminkan keadaan pasar modal.

Perusahaan manufaktur merupakan perusahaan yang bergerak di bidang pembuatan produk. Perusahaan manufaktur yang terdaftar di Bursa Efek Indonesia (BEI) terdiri dari tiga sektor yaitu sektor industri dasar dan kimia, sektor aneka industri dan sektor industri barang konsumsi. Industri manufaktur dipilih sebagai objek penelitian karena industri ini adalah industri yang memiliki perkembangan yang cukup pesat, seperti pada tahun 2012 Sektor industri dasar dan kimia mencatat level tertinggi 485,93, naik 0,42\% atau 2,03 poin (www.investor.co.id). Dengan berkembangnya perusahaan manufaktur yang bagus, maka tidak menutup kemungkinan perusahaan ini sangat dibutuhkan oleh masyarakat dan prospeknya akan menguntungkan dimasa kini maupun di masa yang akan datang.

Penelitian ini berfokus pada perusahaan-perusahaan manufaktur sektor logam dan sejenisnya yang terdaftar di Bursa Efek Indonesia (BEI). Peneliti memilih meneliti pada perusahaan manufaktur sektor logam dan sejenisnya dikarenakan industri manufaktur yang memiliki perkembangan pesat di Indonesia.

Berikut perusahaan manufaktur sektor logam dan sejenisnya yang terdaftar di Bursa Efek Indonesia (BEI) yang dipaparkan pada tabel I.1.

Tabel I.1 Daftar Perusahaan Manufaktur Sub Sektor Logam dan Sejenisnya yang terdaftar di Bursa Efek Indonesia periode 2013-2017

\begin{tabular}{|c|c|c|}
\hline Nomor & Kode & Nama Perusahaan \\
\hline 1 & ALKA & Alakasa Industrindo Tbk. \\
\hline 2 & ALMI & Alumindo Light Metal Industry Tbk. \\
\hline 3 & BTON & Cetonjaya Manunggal Tbk. \\
\hline 4 & CTBN & Gunawan Dianjaya Steel Tbk. \\
\hline 5 & GDST & Indal Aluminium Industry Tbk. \\
\hline 6 & INAI & Jakarta Kyoei Steel Works Tbk. \\
\hline 7 & JKSW & Jaya Pari Steel Tbk. \\
\hline 8 & JPRS & Krakatau Steel (Persero) Tbk. \\
\hline 9 & KRAS & Lion Metal Works Tbk. \\
\hline 10 & LION & Lionmesh Prima Tbk. \\
\hline 11 & LMSH & Pelangi Indah Canindo Tbk. \\
\hline 12 & PICO & Pelat Timah Nusantara Tbk. \\
\hline 13 & NIKL & Tembaga Mulia Semanan Tbk \\
\hline 14 & BAJA & Steel Pipe Industri Of Indonesia Tbk \\
\hline 15 & TBMS & \\
\hline 16 & ISSP & \\
\hline
\end{tabular}

Sumber : www.sahamok.com

Tabel I.1 menggambarkan perusahaan-perusahaan manufaktur sector logam dan sejenisnya yang terdaftar di Bursa Efek Indonesia pada tahun 2013-2017 adalah 16 perusahaan.

"Fenomena yang terjadi di Indonesia dalam pertumbuhan sector manufaktur riil menurun rata-rata dari $11 \%$ per tahun pada periode $1990-1996$, menjadi $4,8 \%$ per tahun pada periode 2001 hingga tahun 2014, hal ini disebabkan karena beberapa faktor yaitu nilai tukar rupiah terhadap dolar AS terdepresiasi sebesar 16\% secara perdagangan tertimbang nominal sejak bulan Desember 2012. Selain itu biaya logistik yang tinggi menjadi penyebab dalam hal infrastruktur dan konektifitas, sehingga rendahnya kinerja manufaktur di tahun 2000 ini menjadi penurunan pertumbuhan ekonomi di Indonesia" (Detik.com, Kamis 18 Agustus 2016 17:35 WIB).

Senada dengan yang diberitakan (Katadata.co.id, diakses 30 Januari 2017) yang berjudul "Investasi Amerika di Indonesia menurun sejak 2014" yang diberitakan pada Jum'at 20 Januari 2016, diberitakan bahwa:

"Setelah mencapai puncaknya pada 2013, investasi Amerika Serikat di Indonesia mengalami penurunan periode 2014-2016. Investasi asing yang berasal dari negeri Paman Sam pada 2013 mencapai US\$ 2,4 miliar meningkat dua kali lipat dari sebelumnya. Namun setelah itu terus mengalami penurunan meskipun jumlah proyeknya bertambah. Hingga triwulan III 2016. Nilai investasi Amerika di Indonesia 
hanya mencapai US\$ 430 juta dengan 343 proyek. Ketidak pastian ekonomi global serta turunnya harga minyak hingga di bawah US\$30 per barel membuat investasi Amerika di Tanah air menyusut. Investasi Amerika di Indonesia sepanjang januari - September 2016 berada di urutan 10. Investasi asing terbesar di Indonesia berasal dari negara Singapura dengan nilai US $\$ 7,1$ miliar".

Harga saham industri manufaktur sangat fluktuatif dan sulit diprediksi. Selain itu, harga saham industri manufaktur sangat rentan terhadap keadaan ekonomi Indonesia. Seperti beberapa tahun yang lalu ketika terjadi krisis global yang membuat harga saham perusahaan industry manufaktur mengalami penurunan. Penurunan harga saham tersebut diakibatkan karena meningkatnya inflasi serta tingkat suku bunga pun mengalami peningkatan.

Adapun rata-rata harga saham perusahaan pada sampel perusahaan Sub Sektor Logam dan sejenisnya yang terdaftar di Bursa Efek Indonesia periode 2013-2017 yang bisa dilihat pada grafik I.1

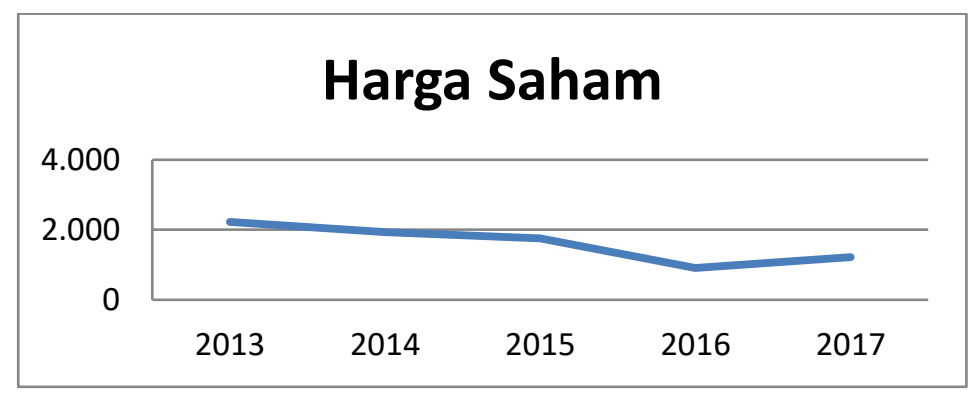

Sumber: www.idx.co.id (data diolah kembali)

\section{Grafik I.1. Rata-Rata Harga Saham Perusahaan Manufaktur Sub Sektor logam dan sejenisnya yang terdaftar di Bursa Efek Indonesia periode 2013-2017}

Grafik 1.1 menunjukkan kondisi rata-rata Harga saham. Pada perusahaan manufaktur sektor logam dan sejenisnya periode 2013-2017 yang fluktuatif. Tahun 2013 berada di angka 2.225. Sementara tahun 2014 harga saham mengalami penurunan menjadi 1.934 dan di tahun berikutnya tepatnya tahun 2015 mengalami penurunan lagi menjadi 1.759,5 dan pada tahun berikutnya yaitu pada tahun 2016 mengalami penurunan lagi menjadi 910 dan pada tahun 2017 mengalami peningkatan kembali menjadi 1.217,25.

Oleh karena itu, keputusan struktur modal merupakan suatu keputusan keuangan yang berkaitan dengan komposisi hutang, saham preferen dan saham biasa yang digunakan perusahaan, manajer harus mampu menghimpun modal baik yang bersumber dari dalam perusahaan maupun dari luar perusahaan secara efisien, dalam arti keputusan pendanan tersebut mampu meminimalkan biaya modal yang harus ditanggung perusahaan (Yuke dan Hadri, 2005). Biaya modal yang muncul dari keputusan pendanaan tersebut merupakan konsekuensi yang secara langsung muncul dari keputusan yang sudah diambil manajer. Saat manajer menggunakan hutang, jelas biaya modal yang timbul yaitu sebesar biaya modal yang sudah dibebankan oleh kreditur sedangkan jika manajer menggunakan dana internal atau dana sendiri, maka akan timbul opportunity cost dari dana atau modal sediri yang telah digunakan. Keputusan pendanaan yang dilakukan secara tidak cermat akan menimbulkan biaya tetap dalam bentuk biaya modal yang tinggi, yang dapat berakibat pada profitabilitas perusahaan.

Disamping itu, struktur modal banyak dipengaruhi oleh berbagi macam faktor. Menurut (Teker et al., 2009) menyatakan faktor-faktor yang mempengaruhi struktur modal adalah profitability, growth opportunity, cost of financial distress dan non-debt tax shield dan selain dari itu ada pula penelitian dari (Yanuar Cristie dan Fuad, 2015) mengemukakan Profitabilitas, Tangibility, Cost Of Financial Distress, dan Non-Debt Tax Shield mempengaruhi struktur modal. Mengingat keputusan pendanaan sangat penting secara langsung dalam menentukan kemampuan perusahaan untuk dapat bertahan dalam persaingan.

Kemudian mengenai variabel non-debt tax shield tentunya penulis harus mengetahui pengertian dari non-debt tax shield terlebih dahulu. Non debt tax shield adalah variabel penentu kebijakan struktur modal dan tidak berhubungan dengan pengurangan pajak penghasilan, karena non debt tax shield bukan sebagai pengurang pendapatan dalam laporan laba rugi yang dapat mengurangin pajak penghasilan. Pengurangan pajak penghasilan (tax shield) merupakan salah satu pertimbangan untuk menentukan kebijakan struktur modal perusahaan. Tax shield tidak hanya diperoleh dari non debt tax shield. Tax shield adalah kelompok penentu struktur modal yang dapat mengurangi atau menambah hutang, terdiri dari: debt tax shields dan non debt tax shield (Djumahir, 2005).

Non debt tax shield merupakan struktur modal yang dapat digunakan sebagai tax shield yang bukan berasal dari hutang, melainkan berupa pembebanan biaya depresiasi dan amortisasi terhadap laba rugi. Biaya 
depresiasi dan amortisasi merupakan biaya yang dapat dikurangkan dari pajak penghasilan menurut Undangundang Pajak Penghasilan No 36 tahun 2008 pasal 6 ayat 1: "Besarnya penghasilan kena pajak bagi wajib pajak dalam negeri dan bentuk usaha tetap, ditentukan berdasarkan penghasilan bruto dikurangi biaya untuk mendapatkan, menagih, dan memelihara penghasilan, termasuk: biaya penyusutan atas pengeluaran untuk memperoleh hak dan atas biaya lain yang mempunyai masa manfaat lebih dari satu tahun sebagaimana dimaksud dalam pasal 1 dan pasa 11A."

Selain itu, mengenai variabel Non debt tax shield terdapat perbedaan hasil penelitian yaitu (Bayradaroglu, 2013), (Hary dan Wiksuana, 2015) dan (Wildani, 2012) menyatakan bahwa non-debt tax shield berpengaruh positif dan signifikan terhadap struktur modal, sedangkan penelitian dari (Erma dan Yad, 2015), (Cortez dan Susanto, 2012), (Liem, et. al., 2013), (Masidonda et al., 2013), dan (Rasoolpur, 2012) menyatakan bahwa variabel non-debt tax shield memiliki pengaruh negatif terhadap struktur modal. Sedangkan penelitian dari (Muhammadinah, 2017) menunjukkan bahwa Non debt tax shield tidak berpengaruh secara signifikan terhadap Struktur Modal.

Sedangkan mengenai variabel Cost of Financial Distress penulis juga harus tahu pengertian dari Cost of Financial Distress. Menurut (Stephen A. Ross, Randolph, Westerfield dan Jeffrey Jeff , 2013:928) financial distress is a situation where a firm's operating cash flows are not sufficient to satisfy current obligations (such as trade credits or interest expenses) and the firm is forced to take corrective action. Artinya kesulitan keuangan adalah suatu keadaan dimana arus kas operasi perusahaan tidak cukup untuk memenuhi kewajibannya saat ini (seperti kredit perdagangan atau beban bunga) dan perusahaan dipaksa untuk mengambil tindakan korektif.

Selain itu, mengenai Cost of Financial Distress terdapat perbedaan hasil penelitian yaitu menurut (Saeed, et al., 2014) menunjukkan bahwa Cost of Financial Distress berpengaruh positif terhadap Struktur Modal. Sedangkan penelitian dari (Handayani, 2011), (Tarazi, 2013), dan (Muhammadinah, 2017) menunjukkan bahwa Cost of Financial Distress tidak berpengaruh secara signifikan terhadap Struktur Modal.

Dalam penelitian ini tidak akan dibahas semua faktor yang mempengaruhi keputusan struktur modal perusahaan, hanya beberapa faktor yang akan dibahas pada penelitian ini yaitu variabel non-debt tax shield dan Cost of Financial Distress

Berdasarkan uraian masalah yang dipaparkan di atas, mengenai variabel non-debt tax shield dan Cost of Financial Distress dan Struktur Modal, maka dapat dirumuskan permasalahanya yaitu: 1). Adakah pengaruh Non-Debt Tax Shield terhadap struktur modal?; 2). Adakah pengaruh Cost Of Financial Distress terhadap struktur modal?; 3).Adakah pengaruh Non-Debt Tax Shield dan Cost Of Financial Distress terhadap struktur modal pada perusahaan sub sektor logam dan sejenisnya yang terdaftar di Bursa Efek Indonesia (BEI) tahun 2013-2017?

\section{Struktur Modal}

\section{KAJIAN LITERATUR}

Struktur modal merupakan bauran atau proporsi pendanaan permanen jangka panjang perusahaan yang diwakili oleh utang, saham preferen, dan ekuitas saham biasa (Horne dan Wachowicz, 2013:232).

Kebijakan mengenai struktur modal melibatkan trade off antara resiko dan tingkat pengembalian. Penggunaan utang yang lebih besar akan meningkatkan resiko perusahaan dan me nyebabkan tingkat pengembalian atas ekuitas akan lebih tinggi. Resiko yang lebih tinggi cenderung menurunkan harga saham, tetapi ekspektasi tingkat pengembalian yang lebih tinggi akan menaikkan harga saham tersebut. Oleh karena itu, struktur modal yang optimal pada suatu perusahaan harus mencapai suatu keseimbangan antara resiko dan pengembalian sehingga dapat memaksimalkan harga saham (Brigham dan Houston, 2012:7).

Struktur modal dapat diukur dengan Debt to Equity Ratio (DER), yaitu mengukur proporsi dana yang bersumber dari utang untuk membiayai aktiva perusahaan. Rasio ini berguna untuk mengetahui jumlah dana yang disediakan peminjam (kreditor) dengan pemilik perusahaan. Dengan kata lain, rasio ini digunakan untuk mengetahui setiap rupiah modal sendiri yang dijadikan untuk jaminan utang (Kasmir, 2013). Debt to Equity Ratio merupakan kemampuan modal sendiri perusahaan dalam memenuhi kewajibannya. Nilai DER yang makin kecil menandakan bahwa perusahaan memiliki jaminan terhadap penggunaan utang yang lebih besar dan sebaliknya. Nilai DER dapat dihitung dengan formulasi sebagai berikut:

$$
D E R=\frac{\text { Total Debt }}{\text { Total Equity }}
$$




\section{Non-Debt Tax Shield}

Menurut Suripto (2015: 8) Non debt tax shield merupakan perlindungan pajak yang memberikan insentif yang kuat terhadap utang, terutama bagi perusahaan yang mempunyai pendapatan kena pajak yang cukup besar. Manfaat pajak dari utang menurun ketika pengurangan pajak lain, seperti kenaikan penyusutan. berikut:

Menurut Undang-undang Pajak Penghasilan No 36 tahun 2008 pasal 6 ayat 1 adalah sebagai

"Besarnya penghasilan kena pajak bagi wajib pajak dalam negeri dan bentuk usaha tetap, ditentukan berdasarkan penghasilan bruto dikurangi biaya untuk mendapatkan, menagih, dan memelihara penghasilan, termasuk: biaya penyusutan atas pengeluaran untuk memperoleh hak dan atas biaya lain yang mempunyai masa manfaat lebih dari satu tahun sebagaimana dimaksud dalam pasal 1 dan pasa 11A."

Perlindungan pajak bukan hutang (non debt tax shield), merupakan instrumen pengganti (substitusi) biaya bunga (interest expense) yang akan berkurang saat memperhitungkan pajak atas laba yang diperoleh perusahaan (Nurita, 2012). Non debt tax shield diukur menggunakan rasio dari jumlah depresiasi terhadap total aset. Pengukuran ini digunakan juga dalam penelitian (Nurita, 2012); (Liem, et al. 2013); dan (Muhammadinah, 2017) sebagai berikut:

\section{Cost Of Finansial Distress}

$$
\text { NDTS }=\frac{\text { Depreciation }}{\text { Total Asset }}
$$

Financial distress terjadi pada saat perusahaan tidak mampu untuk membayar kewajiban financial yang telah jatuh tempo. (Beaver et al., 2010).

financial distress is a situation where a firm's operating cash flows are not sufficient to satisfy current obligations (such as trade credits or interest expenses) and the firm is forced to take corrective action. Artinya kesulitan keuangan adalah suatu keadaan dimana arus kas operasi perusahaan tidak cukup untuk memenuhi kewajibannya saat ini (seperti kredit perdagangan atau beban bunga) dan perusahaan dipaksa untuk mengambil tindakan korektif. (Stephen A. Ross, Randolph, Westerfield dan Jeffrey Jeff , 2013:928)

Cost of Financial Distress, menggambarkan risiko bisnis (business risk), yang merupakan indikator ketidakstabilan harga saham dan return yang diterima oleh pemegang saham. Mengacu pada penelitian dari (Handayani, 2011) dan (Muhammadinah, 2017), variabel Cost of Financial Distress diukur dengan menggunakan standar deviasi dari return saham secara bulanan selama setahun. Secara sistematis, variabel Cost of Financial Distress dapat diformulasikan sebagai berikut:

RISK = Standar Deviasi RETURN SAHAM $/$ Risk $/$ COFD $=\sqrt[2]{\text { Return Saham }}$

Sedangkan untuk menghitung Return Saham, dapat dilakukan dengan rumus berikut:

\section{Kerangka Pemikiran}

$$
\text { Return Saham }=\frac{\text { Harga Saham }_{t}-\text { Harga Saham }_{t-1}}{\operatorname{HargaSaham}_{t-1}}
$$

Bagan II.1 Model Penelitian Pengaruh Variabel Non-Debt Tax Shield, dan Cost Of Financial Distress Terhadap Struktur Modal

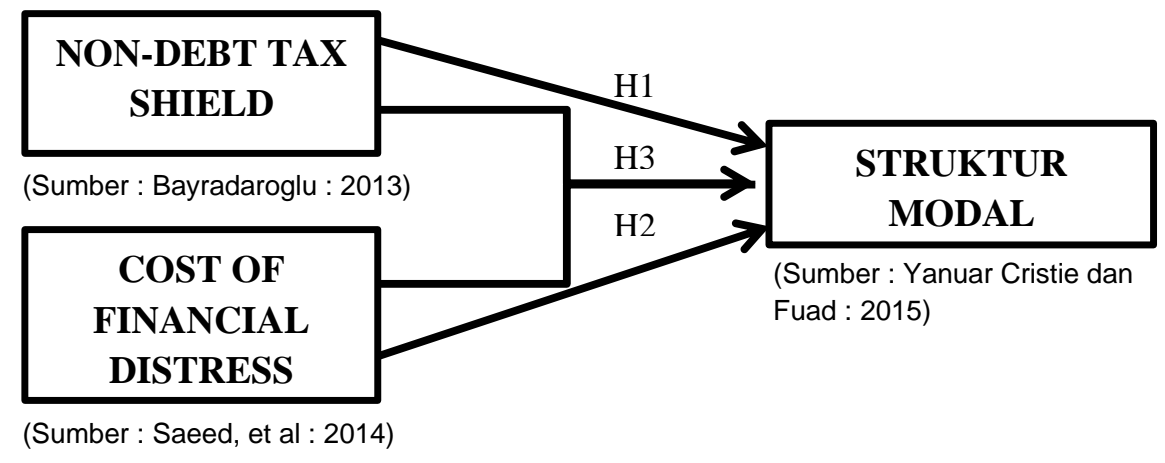

Hipotesis

Berdasarkan pokok permasahalan yang ada yang didukung oleh teori yang dikemukakan diatas, maka peneliti merumuskan suatu hipotesis dalam penelitian ini sebagai berikut:

H1 = Terdapat Pengaruh secara parsial antara Non-Debt Tax Shield terhadap Struktur Modal

H2 = Terdapat Pengaruh secara parsial antara Cost Of Financial Distress terhadap Struktur Modal.

H3 = Terdapat Pengaruh secara bersama-sama/simultan antara Non-Debt Tax Shield dan Cost Of Financial Distress terhadap Struktur Modal. 


\section{METODE PENELITIAN}

\section{Pendekatan dan Jenis Penelitian}

Penelitian ini menggunakan pendekatan kuantitatif. Penelitian kuantitatif merupakan penelitian yang menekankan pada pengujian teori - teori dan atau hipotesis - hipotesis melalui pengukuran variabel variabel penelitian dan angka (quantitative) dan melakukan analisis data dengan prosedur dan atau permodelan matematis (Sujoko Efferin, 2008:47). Variabel-variabel yang akan diuji adalah variabel dependen yaitu struktur modal dan variabel independen yang terdiri dari non-debt tax shield dan cost of finansial distress sebagai variabel independen. Kemudian berdasarkan analisa yang akan dilakukan maka akan ditentukan apakah variabel-variabel tersebut berpengaruh terhadap struktur modal.

Jenis penelitian ini menggunakan metode korelasi. Menurut Sukardi (2009:166) penelitian korelasi adalah suatu penelitian yang melibatkan tindakan pengumpulan data guna menentukan, apakah ada hubungan dan tingkat hubungan antara dua variabel atau lebih.

\section{Operasionalisasi Variabel}

Adapun pengukuran variabel-variabel dalam penelitian ini meliputi variabel terikat (variabel dependen) dan variabel bebas (variabel independen), yaitu:

\section{Variabel Independen $(X)$}

\section{a. Non-Debt Tax Shield (X1)}

Perlindungan pajak bukan hutang (non debt tax shield), merupakan instrumen pengganti (substitusi) biaya bunga (interest expense) yang akan berkurang saat memperhitungkan pajak atas laba yang diperoleh perusahaan (Nurita, 2012). Non debt tax shield diukur menggunakan rasio dari jumlah depresiasi terhadap total aset. Pengukuran ini digunakan juga dalam penelitian (Nurita, 2012); (Muhammadinah, 2017); dan (Liem, et al., 2013) sebagai berikut:

$$
\text { NDTS }=\frac{\text { Depreciation }}{\text { Total Asset }}
$$

Pada penelitian ini, data untuk variabel X1 (Non-Debt Tax Shield) diperoleh dari penghitungan rumus di atas. Data Depreciation dan Total Aset didapat melalui Laporan Keuangan Perusahaan Manufaktur yang terdaftar di Bursa Efek Indonesia (BEI).

\section{b. Cost Of Financial Distress (X2)}

Cost of Financial Distress, menggambarkan risiko bisnis (business risk), yang merupakan indikator ketidakstabilan harga saham dan return yang diterima oleh pemegang saham. Mengacu pada penelitian dari (Handayani, 2011) dan (Muhammadinah, 2017), variabel Cost of Financial Distress diukur dengan menggunakan standar deviasi dari return saham secara bulanan selama setahun. Secara sistematis, variabel Cost of Financial Distress dapat diformulasikan sebagai berikut: RISK $=$ Standar Deviasi RETURN SAHAM $/$ Risk/COFD $=\sqrt[2]{\text { Return Saham }}$

Sedangkan untuk menghitung Return Saham, dapat dilakukan dengan rumus berikut:

$$
\text { Return Saham }=\frac{\text { Harga Saham }_{t}-\text { Harga Saham }_{t-1}}{\operatorname{HargaSaham}_{t-1}}
$$

Pada penelitian ini, data untuk variabel X2 (Cost of Financial Distress) diperoleh dari penghitungan rumus di atas. Data harga saham didapat melalui Laporan Keuangan Perusahaan Manufaktur yang terdaftar di Bursa Efek Indonesia (BEI).

\section{Sumber Data dan Teknik Pengumpulan Data}

Penelitian ini menggunakan data sekunder, yaitu data yang terkait dengan variabel-variabel yang diteliti: non-debt tax shield, dan cost of financial distress dari laporan keuangan perusahaan Sub Sektor Logam yang terdaftar di Bursa Efek Indonesia (BEI) selama periode waktu 2013-2017. Data-data yang telah dikumpulkan ini diperoleh dari laporan keuangan perusahaan yang diperoleh dari situs resmi Bursa Efek Indonesia (www.idx.co.id). 
Untuk mendapatkan hasil penelitian yang diharapkan, penulis membutuhkan berbagai data dan informasi yang mendukung penelitian ini. Metode pengumpulan data yang dilakukan penulis dalam penelitian ini, yaitu sebagai berikut :

1. Metode Studi Pustaka (Library Research)

Studi kepustakaan ini dilakukan dengan cara mempelajari buku-buku, artikel, jurnal-jurnal, situs internet, maupun karya tulis lainnya yang berkaitan atau berhubungan dengan masalah yang diteliti dalam penelitian ini.

2. Metode Dokumentasi

Untuk mendapatkan dan mengumpulkan data laporan keuangan perusahaan manufaktur yang akan digunakan dalam penelitian ini, penulis melakukan pencarian data tersebut lewat browsing ke situs Bursa Efek Indonesia (BEI) (www.idx.co.id)

\section{Populasi dan Teknik Sampling}

1. Populasi

Sampling Populasi adalah kelompok elemen yang lengkap, yang biasanya berupa orang, objek, transaksi, atau kejadian dimana kita tertarik untuk mempelajarinya atau menjadi objek penelitian (Kuncoro, 2012: 118). Sedangkan sampel yaitu suatu himpunan bagian (subset) dari unit populasi.

Populasi yang menjadi objek dalam penelitian ini adalah perusahaan sub sektor logam yang terdaftar di Bursa Efek Indonesia (BEI) periode tahun 2013-2017 yaitu sebanyak 16 perusahaan Sub Sektor logam yang terdaftar di Bursa Efek Indonesia (BEI).

\section{Teknik Sampling}

Menurut Sugiyono (2010:119) teknik sampling adalah "Teknik pengambilan sampel untuk menentukan sampel yang digunakan dalam penelitian."

Teknik sampling yang digunakan oleh penulis adalah non probability sampling. Menurut Sugiyono (2010:120) non probability sampling adalah: "Teknik pengambilan sampel yang memberi peluang/kesempatan sama bagi setiap unsur atau anggota populasi untuk dipilih menjadi sampel. Teknik sampel ini meliputi, sampling sistematis, kuota, aksidental, purposive, jenuh, snowball."

Teknik non probability sampling yang digunakan dalam pengambilan sampel pada penelitian ini yaitu teknik sampling jenuh. Pengertian sampling jenuh menurut Sugiyono (2015:85) adalah teknik penentuan sampel bila semua anggota populasi digunakan sebagai sampel. Hal ini sering dilakukan bila jumlah populasi relative kecil, kurang dari 30 orang, atau penelitian yang ingin membuat generalisasi dengan kesalahan yang sangat kecil. Istilah lain sampel jenuh adalah sensus, dimana semua anggota populasi dijadikan sampel.

Dalam penelitian ini yang menjadi sampel penelitian adalah 16 perusahaan. Dimana pengambilan sampel dalam penelitian ini berdasarkan teknik jenuh yaitu teknik penentuan sampel dimana semua populasi diambil sebagai sampel yang mana jumlah sampelnya sebanyak 16 perusahaan sub sektor logam dan sejenisnya yang terdaftar di Bursa Efek Indonesia (BEI).

\section{Teknik Analisis Data}

Menurut Sugiyono (2014:206) analisis data adalah:

"Kegiatan setelah seluruh data terkumpul. Kegiatan dalam analisis data adalah mengelompokkan data berdasarkan variabel dari seluruh responden, menyajikan data tiap variabel yang diteliti, melakukan perhitungan untuk menjawab rumusan masalah dan melakukan perhitungan untuk menguji hipotesis yang telah diajukan”.

Analisis data merupakan penyederhanaan data kedalam bentuk yang mudah dipahami, dibaca dan diinterprestasikan. Data yang terhimpun dari hasil penelitian akan penulis bandingkan antara data yang ada di lapangan dengan data kepustakaan, kemudian dilakukan analisis untuk menarik kesimpulan. Berdasarkan jenis data dan analisis, penelitian ini adalah jenis penelitian kuantitatif. Dalam melakukan analisis terhadap data yang dikumpulkan untuk mencapai suatu kesimpulan, penulis melakukan perhitungan pengolahan dan penganalisaan dengan bantuan dari program Software IBM SPSS Statistik 24 untuk meregresikan model yang telah dirumuskan.

Analisis data yang digunakan oleh penulis dalam penelitian ini adalah Analisis Deskriptif dan Analisis Persamaan Berganda (Multiple Regression).

\section{Analisis Statistik Deskripsi}

Muhammad Yusuf, et al. (Pengaruh Non-Debt Tax Shield Dan Cost Of Financial Distress ...) 
Statistik deskriptif adalah statistik yang digunakan untuk menganalisa data dengan cara mendeskripsikan atau menggambarkan data yang telah terkumpul sebagaimana adanya tanpa bermaksud membuat kesimpulan yang berlaku untuk umum atau generalisasi (Sugiyono, 2014:206).

\section{Analisis Persamaan Berganda (Multiple Regression).}

Teknik analisis data dalam penelitian ini, yaitu dengan menggunakan teknik persamaan regresi berganda (Multiple Regression). Analisis regresi ini merupakan teknik statistik yang digunakan peneliti untuk mencari persamaan regresi, yang dapat digunakan untuk memprediksi besar variabel dependen di masa yang akan datang karena adanya pengaruh dari beberapa variabel independen atau variabel bebas.

Persamaan regresi berganda (Multiple Regression) dalam penelitian ini adalah sebagai berikut:

$\mathrm{Y}=\mathrm{a}+\mathrm{b} 1 \mathrm{X} 1+\mathrm{b} 2 \mathrm{X} 2 \ldots$

Keterangan:

$$
\begin{array}{ll}
\mathrm{Y} & =\text { Struktur Modal } \\
\mathrm{a} & =\text { Konstanta } \\
\mathrm{b} 1,2 & =\text { Koefisien Regresi Variabel X } \\
\mathrm{X} 1 & =\text { Non-Debt Tax Shield } \\
\mathrm{X} 2 & =\text { Cost Of Financial Distress }
\end{array}
$$

\section{a. Uji Asumsi Klasik}

Model regresi terlebih dahulu harus memenuhi pengujian asumsi klasik untuk mengetahui apakah model regresi dalam penelitian benar-benar menunjukkan hubungan yang signifikan yang meliputi:

\section{1). Uji Normalitas}

Uji Normalitas ini digunakan untuk menguji apakah dalam model regresi, variabel pengganggu/residual atau variabel dependen dan independennya memiliki distribusi normal (Gozhali, 2009). Model regresi yang baik adalah memiliki distribusi data normal atau mendekati normal. Terdapat dua cara untuk mengetahui apakah residual terdistribusi normal atau tidak, yaitu dengan analisis grafik dan uji statistik.

Apabila menggunakan analisis grafik, normalitas data dapat diketahui dengan melihat grafik histrogram yang membandingkan antara data observasi dengan distribusi yang mendekati distribusi normal, selain itu dapat juga dengan melihat normal probability plot, yaitu dengan membandingkan distribusi kumulatif dari data sesungguhnya dengan distribusi normal. Distribusi normal akan membentuk satu garis lurus diagonal dan ploting data residual akan dibandingkan dengan garis diagonalnya. Jika data atau titik-titik menyebar disekitar garis diagonal dan mengikuti arah garis diagonal, maka model regresi yang digunakan telah memenuhi asumsi normalitas.

Model regresi yang baik adalah data yang berdistribusi normal atau mendekati normal. Apabila asumsi ini dilanggar, maka uji statistik yang dilakukan menjadi bias atau tidak valid, terutama untuk sampel yang kecil.

\section{2). Uji Multikolinearitas}

Tujuan Uji multikolinearitas ini adalah untuk menguji apakah dalam model regresi ditemukan adanya korelasi yang kuat antar variabel independen (Ghozali, 2009). Apabila terjadi korelasi yang kuat, maka terdapat masalah multikolinearitas yang harus diatasi. Dalam penelitian ini, pengujian multikolinearitas untuk mengetahui ada atau tidaknya multikolinearitas di dalam model regresi dapat dilihat dari :

a. nilai Tolerance

b. Variance Inflation Factor (VIF). Kriteria yang digunakan dalam pengujian ini, yaitu apabila nilai Tolerance $\leq 0,10$ atau sama dengan nilai VIF $\geq 10$, maka terdapat masalah multikolinearitas antara variabel independen (Ghozali, 2009: 96).

Model regresi yang baik, yaitu tidak terdapatnya masalah multikolinearitas atau korelasi diantara variabel-variabel independennya.

3). Uji Heteroskedastisitas 
Penggunaan uji heteroskedastisitas ini adalah untuk mengetahui apakah dalam sebuah model regresi terjadi ketidaksamaan varians dari residual (error) satu pengamatan ke pengamatan lain. Jika varians dari residual dari satu pengamatan ke pengamatan yang lain tetap, maka disebut homoskedastisitas, dan apabila varians berbeda disebut heteroskedastisitas. Model regresi yang baik dalam suatu penelitian adalah seharusnya tidak terjadi heteroskedastisitas (Gozhali, 2009).

Pengujian asumsi ini dapat diilakukan dalam berbagai cara, diantaranya dengan metode grafik yaitu dengan melihat grafik scatter plot, White's General Heteroscedasticity Test, Uji Glejser, dan Park Test. Pada penelitian ini, alat uji yang digunakan untuk mendeteksi ada atau tidaknya heteroskedastisitas adalah dengan menggunakan analisis grafik scatter plot. Dasar analisis pengujian heteroskedastisitas menggunakan grafik scatter plot,yaitu sebagai berikut (Gozhali, 2009) :

a. Jika tidak ada pola yang jelas serta titik-titik menyebar diatas dan dibawah angka 0 pada sumbu Y, maka tidak terjadi gejala heteroskedastisitas.

b. Jika ada pola tertentu, seperti titik-titik yang ada membentuk pola tertentu yang teratur (seperti, bergelombang, melebar kemudian menyempit), maka menunjukkan telah terjadi heteroskedastisitas (Gozhali, 2009).

4). Autokorelasi

Uji autokorelasi bertujuan menguji apakah dalam model regresi linear ada korelasi antara kesalahan pengganggu pada periode $\mathrm{t}$ dengan kesalahan pengganggu pada periode $\mathrm{t}-1$ (sebelumnya) (Imam Ghozali, 2013:110). Autokorelasi muncul karena observasi yang berurutan sepanjang waktu berkaitan satu sama lainnya. Hal ini sering ditemukan pada data runtut waktu (time series) karena "gangguan" pada seseorang individu atau kelompok cenderung mempengaruhi "gangguan" pada individu atau kelompok yang sama pada periode berikutnya. Pada penelitian ini untuk menguji ada tidaknya gejala autokorelasi menggunakan uji Durbin-Watson (DW test).

Tabel III. 1. Pengambilan keputusan ada tidaknya autokorelasi

\begin{tabular}{|l|c|c|}
\hline \multicolumn{1}{|c|}{ Hipotesis } & Keputusan & Jika \\
\hline Tidak ada autokorelasi positif & Tolak & $0<\mathrm{d}<\mathrm{dl}$ \\
\hline Tidak ada autokorelasi positif & No Decision & $\mathrm{dl} \leq \mathrm{d} \leq \mathrm{du}$ \\
\hline Tidak ada korelasi negatif & Tolak & $4-\mathrm{dl}<\mathrm{d}<4$ \\
\hline Tidak ada korelasi negatif & No Decision & $4-\mathrm{du} \leq \mathrm{d} \leq 4-\mathrm{dl}$ \\
\hline Tidak ada autokorelasi, positif atau negatif & Tidak Ditolak & $\mathrm{du}<\mathrm{d}<4-\mathrm{du}$ \\
\hline
\end{tabular}

Dalam penelitian ini, peneliti menggunakan pendekatan Durbin Waston (DW test), dikarenakan sampel yang digunakan dibawah 100. Sedangkan jika sampel diatas 100 maka harus menggunakan pendekatan Lagrange Multiplier (LM test). Uji Durbin-Woston hanya digunakan untuk autokorelasi tingkat satu dan mensyaratkan adanya konstanta dalam model regresi dan tidak ada variabel lag diantara variabel independent (Imam Ghozali, 2013:111).

\section{b. Uji Hipotesis}

\section{Uji Signifikansi Parameter Individual (Uji t)}

Uji Hipotesis yang pertama adalah uji t, digunakan untuk melihat pengaruh masing-masing variabel bebas (independen) secara parsial terhadap variabel terikat (dependen) dengan prosedur sebagai berikut :

a. Menentukan hipotesis masing-masing kelompok:

$\mathrm{H} 0=$ Variabel independen secara parsial atau individu tidak berpengaruh terhadap variabel dependen.

$\mathrm{H} 1=$ Variabel independen secara parsial atau individu memiliki pengaruh terhadap variabel dependen.

b. Membandingkan nilai t hitung dengan $t$ tabel dengan kriteria sebagai berikut:

1). Jika t-hitung < t-tabel, maka variabel independen secara individual tidak berpengaruh terhadap variabel dependen (H0 diterima).

2). Jika t-hitung > t-tabel, maka variabel independen secara individual berpengaruh terhadap variabel dependen (H0 ditolak). 
c. Menentukan tingkat signifikansi yaitu $\alpha=0,05$ (5\%).

d. Dalam penelitian ini juga dilakukan dengan melihat nilai tingkat signifikansi $0,05(\alpha=5 \%)$ dengan derajat bebas $(n-k)$, dimana $n=$ jumlah pengamatan dan $k=$ jumlah variabel. Dengan kriteria pengujian :

1). Apabila tingkat signifikansi $>0,05$ maka Ho ditolak dan $\mathrm{H} 1$ diterima, berarti tidak ada pengaruh antara variabel bebas dengan variabel terikat.

2). Apabila tingkat signifikansi $<0,05$ maka Ho diterima dan $\mathrm{H} 1$ ditolak, berarti ada pengaruh antara variabel bebas dengan variabel terikat.

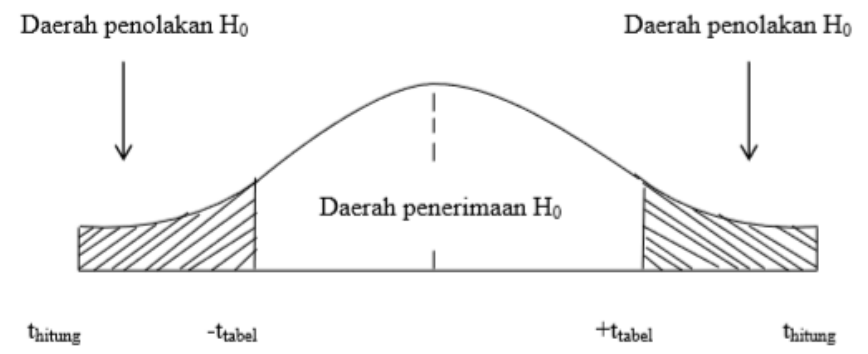

Gambar III. 1. Daerah penerimaan dan Penolakan H0 (Uji t)

2. Uji Signifikansi/ Pengaruh Simultan (Uji F)

Menurut Ghozali (2016;96) Uji F disini bertujuan untuk mengetahui apakah variabel bebas (independen) secara bersama-sama berpengaruh terhadap variabel terikat (dependen). Prosedur yang dapat digunakan adalah sebagai berikut :

a. Dalam penelitian ini digunakan tingkat signifikansi 0,05 dengan derajat bebas ( $\mathrm{n}-\mathrm{k}$ ), dimana $\mathrm{n}$ : jumlah pengamatan dan $\mathrm{k}$ : jumlah variabel.

b. Kriteria keputusan :

1. Uji Kecocokan model ditolak jika $\alpha>0,05$

2. Uji Kecocokan model diterma jika $\alpha<0,05$.

\section{Koefisien Determinasi (Uji $\left.\mathrm{R}^{2}\right)$}

Koefisien determinasi $\mathrm{R}^{2}$ pada intinya mengukur seberapa jauh kemampuan model dalam menerangkan variabel - variabel dependen (Ghozali, 2016;95). Nilai koefisien determinasi adalah nol dan satu. Nilai $R^{2}$ yang kecil berarti kemapuan variabel-variabel independen dalam menjelaskan variasi variabel dependen sangat terbatas. Nilai yang mendekati satu berarti variabelvariabel independen memberikan hampir semua informasi yang dibutuhkan untuk memprediksi variasi variabel dependen (Ghozali, 2016;95).

\section{HASIL PENELITIAN DAN PEMBAHASAN}

\section{Hasil Penelitian}

\section{Hasil Analisis Statistik Deskriptif}

Statistik deskriptif bertujuan untuk memberikan gambaran atau deskripsi suatu data yang dilihat dari jumlah data, nilai minimum, nilai maksimum, nilai rata-rata, dan standar deviasi. Statistik deskriptif dapat mencerminkan beberapa karakter sampel. Deskriptif yang terapat dalam penelitian ini meliputi jumlah sampel penelitian, nilai minimum variabel penelitian, nilai maksimum penelitian, nilai rata-rata variable penelitian, dan standar deviasi atau penyimpangan dari satu variable dependen dan variabel independen. Hasil statistik deskriptif dalam penelitian ini adalah sebagai berikut:

Tabel IV.1 Hasil Analisis Statistik Deskriptif

\begin{tabular}{|c|c|c|c|c|c|c|}
\hline Variabel & N & Range & Minimum & Maximum & Mean & $\begin{array}{c}\text { Std. } \\
\text { Deviation }\end{array}$ \\
\hline NDTS & 80 & 0,68 & 0,01 & 0,69 & 0,2308 & 0,16098 \\
\hline
\end{tabular}




\begin{tabular}{|c|c|c|c|c|c|c|}
\hline COFD & 80 & 6,63 & 0,00 & 6,63 & 0,6269 & 0,77953 \\
\hline $\begin{array}{c}\text { Struktur } \\
\text { Modal }\end{array}$ & 80 & 11,84 & $-1,73$ & 10,11 & 1,7655 & 2,11506 \\
\hline
\end{tabular}

Sumber : Hasil Output SPSS 24 (Data diolah Penulis)

Berdasarkan hasil statistik deskriptif tabel IV.1 tersebut, menunjukkan bahwa dalam penelitian ini terdapat 1 variabel dependen yaitu struktur modal dan 2 variabel independen yaitu non debt tax shield dan cost of financial distress. Jumlah data penelitian masing-masing dari setiap variabel dependen dan independen adalah sebanyak 80 data dari tahun 2013-2017 yang ditunjukkan dengan nilai N. Berikut adalah penjelasan dari masing-masing variabel:

a) Variabel non debt tax shield (NDTS) memiliki nilai minimum sebesar 0,01 dan nilai maksimum sebesar 0,69. Hal ini menunjukkan bahwa dari total keseluruhan data penelitian variabel non debt tax shield (NDTS) yang berjumlah 80 data, besarnya non debt tax shield (NDTS) perusahaan yang diukur dengan total depresiasi dibagi total aset berkisar antara 0,01 hingga 0,69 dengan nilai mean atau ratarata sebesar 0,2308 dan nilai standar deviasi sebesar 0,16098. Nilai mean pada variabel ini lebih tinggi daripada nilai standar deviasinya. Sehingga variabel non debt tax shield (NDTS) tidak menggambarkan fluktuasi data yang tinggi.

b) Variabel cost of financial distress (COFD) memiliki nilai minimum sebesar 0,00 dan nilai maksimum sebesar 6,63. Hal ini menunjukkan bahwa dari total keseluruhan data penelitian variabel cost of financial distress (COFD) yang berjumlah 80 data, besarnya cost of financial distress (COFD) perusahaan yang diukur dengan akar kuadrat dari saham return berkisar antara 0,00 hingga 6,63 dengan nilai mean atau rata-rata sebesar 0,6269 dan nilai standar deviasi sebesar 0,77953. Nilai mean pada variabel ini lebih tinggi daripada nilai standar deviasinya. Sehingga variabel cost of financial distress (COFD) tidak menggambarkan fluktuasi data yang tinggi.

c) Variabel struktur modal memiliki nilai minimum sebesar $-1,73$ dan nilai maksimum sebesar 10,11. Hal ini menunjukkan bahwa dari total keseluruhan data penelitian variabel struktur modal yang berjumlah 80 data, besarnya struktur modal perusahaan yang diukur dengan total hutang dibagi total modal berkisar antara -1,73 hingga 10,11 dengan nilai mean atau rata-rata sebesar 1,7655 dan nilai standar deviasi sebesar 2,11506. Nilai mean pada variabel ini lebih rendah daripada nilai standar deviasinya. Sehingga variabel struktur modal menggambarkan fluktuasi data yang tinggi.

\section{Hasil Uji Asumsi Klasik}

\section{1). Hasil Uji Normalitas}

Uji normalitas bertujuan untuk menguji apakah dalam model regresi, variabel pengganggu atau residual memiliki distribusi yang normal. Jika asumsi ini dilanggar maka uji statistik menjadi tidak valid untuk jumlah sampel yang kecil. Uji normalitas dalam penelitian ini menggunakan data dari residual dan memakai One-Sample Kolmogorov-Smirnov Test dengan melihat nilai Asymp Sig (2tailed) nya. Uji normalitas diukur dengan tingkat signifikansi sebesar 5\% atau 0,05. Apabila nilai signifikansi lebih dari 0,05 maka data dalam penelitian ini memiliki distribusi yang normal. Tetapi jika nilai signifikansi kurang dari 0,05 maka data dalam penelitian ini tidak berdistribusi normal. Hasil uji normalitas dalam penelitian ini adalah sebagai berikut:

Tabel IV. 2. Hasil Uji Normalitas

\begin{tabular}{|l|c|}
\hline & Unstandardized Residual \\
\hline $\mathrm{N}$ & 80 \\
\hline Kolmogorov-Smirnov Z & 0,086 \\
\hline Asymp. Sig. (2-tailed) & 0,200 \\
\hline
\end{tabular}

Sumber : Hasil Output SPSS 24 (Data diolah Penulis)

Hasil uji normalitas pada variabel dependen menunjukkan nilai Asymp.Sig (2 tailed) sebesar 0,200 yang berarti melebihi taraf signifikansi sebesar 0,05 atau $5 \%$.

Jadi dapat disimpulkan bahwa data dalam penelitian ini berdistribusi normal dan data tersebut layak untuk diuji. Adapun dalam pengujian normalitas ini, penulis juga memaparkan uji normalitas data yang dilakukan untuk mengetahui distribusi penyebaran data dengan menggunakan grafik Normal P-P Plot diperoleh hasil sebagai berikut: 


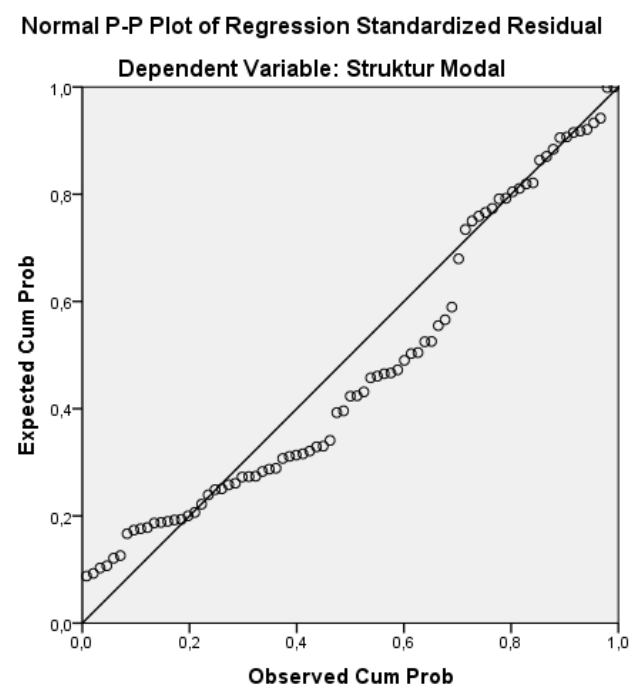

\section{Grafik IV.1 Normal P-P Plot \\ Sumber : Hasil Output SPSS 24 (Data diolah Penulis)}

Berdasarkan gambar grafik di atas diperoleh hasil bahwa penyebaran titik-titik mendekati garis diagonal, hal ini menunjukkan bahwa data berdistribusi normal.

2). Hasil Uji Multikolinearitas

Uji multikolonearitas bertujuan untuk menguji apakah dalam model regresi terdapat korelasi antar variabel bebas (independen). Model regresi yang baik adalah tidak terjadi korelasi diantara variabel independen. Uji multikolinearitas dalam penelitian ini yaiu dengan melihat nilai variance inflation factor (VIF) dan tolerance. Jika nilai VIF $>10$ atau jika nilai tolerance $<10$ atau jika nilai tolerance $>0,10$ maka tidak terjadi multikolonearitas dalam model regresi. Hasil uji multikolonearitas dapat dilihat di tabel IV.

Tabel IV. 3 Hasil Uji Multikolonearitas

\begin{tabular}{|c|c|c|l|}
\hline Variabel & Tolerance & VIF & \multicolumn{1}{|c|}{ Keterangan } \\
\hline NDTS & $0,989>0,10$ & $1,011<10$ & $\begin{array}{l}\text { tidak terjadi } \\
\text { multikolonearitas }\end{array}$ \\
\hline COFD & $0,989>0,10$ & $1,011<10$ & $\begin{array}{l}\text { tidak terjadi } \\
\text { multikolonearitas }\end{array}$ \\
\hline
\end{tabular}

Sumber: Hasil Olah Data SPSS 24 (Data diolah Penulis)

Dari tabel hasil uji multikolonearitas dapat dilihat bahwa semua variabel independen dalam penelitian ini memiliki nilai nilai tolerance diatas angka 0,10 dan nilai VIF dibawah angka 10. Jadi dapat disimpulkan bahwa data dalam penelitian ini tidak terjadi multikolonearitas dan data tersebut layak untuk diuji.

\section{3). Hasil Uji Heteroskedastisitas}

Uji heterokedastisitas bertujuan untuk menguji apakah dalam model regresi terjadi perbedaan variance dari residual suatu pengamatan ke pengamatan yang lain. Model regresi yang baik adalah yang tidak terjadi heteroskedastisitas dimana variance residual satu pengamatan ke pengamatan lain adalah konstan. Uji heteroskedastisitas dalam penelitian ini dengan melihat grafik scatter plot. Jika titik membentuk pola yang teratur, maka telah terjadi heteroskedastisitas dalam model regresi. Sebaliknya, jika tidak terdapat pola yang jelas, titik menyebar diatas dan dibawah angka nol tidak terjadi heteroskedastisitas dalam model regresi. Hasil uji heteroskedastisitas dalam penelitian ini yaitu: 


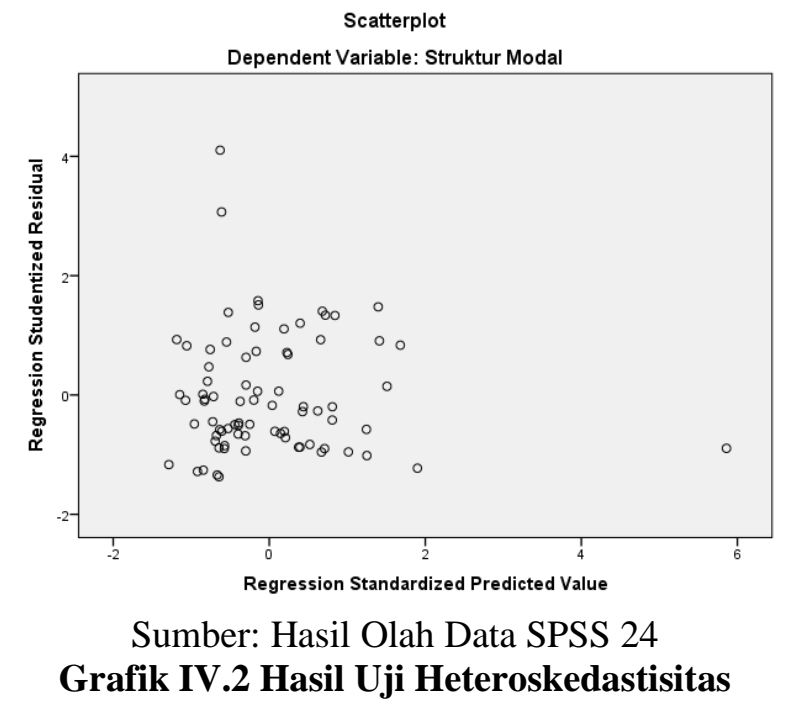

Dari grafik scatter plot IV.2 tersebut, terlihat bahwa titik tidak membentuk pola yang jelas dan teratur, titik menyebar diatas dan dibawah angka nol. Jadi dapat disimpulkan bahwa data dalam penelitian ini tidak terjadi heteroskedastisitas dan data tersebut layak untuk diuji.

\section{4). Hasil Uji Autokorelasi}

Uji autokorelasi bertujuan untuk menguji apakah dalam model regresi linear terdapat korelasi antara kesalahan pengganggu pada periode $\mathrm{t}$ dengan kesalahan pengganggu pada periode $\mathrm{t}-1$ (sebelumnya). Model regresi yang baik adalah regresi yang bebas dari autokorelasi. Uji autokorelasi dalam penelitian ini diukur dengan Durbin Watson (DW). Untuk mengetahui ada tidaknya autokorelasi, dilakukan dengan pengujian terhadap nilai DW kemudian dibandingkan dengan perhitungan nilai dU dan 4-dU yang dibantu dengan tabel Durbin Watson. Hasil uji autokorelasi dalam penelitian ini adalah sebagai berikut:

Tabel IV.4. Hasil Uji Autokorelasi

\begin{tabular}{|c|c|c|c|c|c|}
\hline \multicolumn{6}{|c|}{ Model Summary $^{\mathbf{b}}$} \\
\hline Model & $\mathrm{R}$ & $\begin{array}{c}\mathrm{R} \\
\text { Square }\end{array}$ & $\begin{array}{c}\text { Adjusted R } \\
\text { Square }\end{array}$ & $\begin{array}{l}\text { Std. Error of } \\
\text { the Estimate }\end{array}$ & $\begin{array}{c}\text { Durbin- } \\
\text { Watson }\end{array}$ \\
\hline 1 &, $239^{\mathrm{a}}$ &, 057 &, 032 & 2,07942 & 2,006 \\
\hline
\end{tabular}

a. Predictors: (Constant), COFD, NDTS

b. Dependent Variable: Struktur_Modal

Sumber: Hasil Output Olah Data SPSS 24

Dari hasil uji autokorelasi tabel IV.6 tersebut, dapat dlilihat bahwa nilai Durbin Watson (DW) sebesar 2,006. Nilai tersebut kemudian dibandingkan dengan nilai dU dan 4dU yang diambil dari tabel Durbin Watson untuk alpha (a) $=5 \%$ dengan ketentuan $\mathrm{n}=80$ dan $\mathrm{k}=2$, maka diproleh hasil dU sebesar 1,688. Setelah mengetahui nilai dU, kemudian dilakukan perhitungan (4-dU) yang diperoleh hasil 4-dU sebesar 2,312. Ketentuan nilai DW jika tidak terdapat autokorelasi adalah apabila d terletak diantara dU dan (4-dU). Pada hasil uji autokorelasi tersebut nilai DW sebesar 2,006 yang terletak diantara dU dan (4-dU). Jadi dapat disimpulkan bahwa dalam penelitian ini tidak terjadi autokorelasi dan data tersebut layak untuk diuji.

\section{Hasil Analisis Regresi Berganda}

Analisis regresi berganda bertujuan untuk menjelaskan bentuk pengaruh hubungan antara variabel bebas $(\mathrm{X})$ terhadap variabel terikat $(\mathrm{Y})$. Hasil uji regresi berganda dalam penelitian ini yaitu: 
Tabel IV. 5. Hasil Uji Regresi Berganda

\begin{tabular}{|c|c|c|c|c|c|c|}
\hline \multicolumn{7}{|c|}{ Coefficients $^{\mathbf{2}}$} \\
\hline \multirow{2}{*}{ Model } & \multicolumn{2}{|c|}{$\begin{array}{c}\text { Unstandardized } \\
\text { Coefficients }\end{array}$} & $\begin{array}{c}\text { Standardize } \\
\text { d } \\
\text { Coefficients }\end{array}$ & \multirow{2}{*}{ t } & \multirow{2}{*}{ Sig. } \\
\cline { 3 - 8 } & & B & Std. Error & Beta & & \\
\hline \multirow{3}{*}{1} & (Constant) & 1,024 &, 539 & & 1,900 & \multirow{2}{*}{, 061} \\
\cline { 2 - 8 } & NDTS & 2,038 & 1,455 &, 157 & 1,401 &, 165 \\
\cline { 2 - 7 } & COFD &, 529 &, 301 &, 197 & 1,756 &, 083 \\
\hline
\end{tabular}

Sumber: Hasil Output Olah Data SPSS 24

Sesuai dengan hasil pengolahan data di atas, maka didapat persamaan regresi linear berganda sebagai berikut:

$Y=1,024+2,038 X_{1}+0,529 X_{2}$

Dari persamaan regresi tersebut, maka diperoleh interprestasi sebagai berikut:

a. Nilai konstanta sebesar 1,024 menunjukkan bahwa tanpa adanya variabel non debt tax shield $\left(\mathrm{X}_{1}\right)$ dan cost of financial distress $\left(\mathrm{X}_{2}\right)$ maka nilai struktur modal hanya sebesar 1,024.

b. Nilai koefisien regresi non debt tax shield $\left(\mathrm{X}_{1}\right)$ sebesar 2,038 menunjukkan bahwa kenaikan variabel non debt tax shield $\left(\mathrm{X}_{1}\right)$ sebesar 1\% maka akan meningkatkan struktur modal sebesar 2,038\% dengan asumsi variabel lain dianggap konstan.

c. Nilai koefisien regresi variabel variabel cost of financial distress $\left(\mathrm{X}_{2}\right)$ sebesar 0,529 menunjukkan bahwa kenaikan variabel cost of financial distress $\left(\mathrm{X}_{2}\right)$ sebesar $1 \%$ maka akan meningkatkan struktur modal sebesar 0,529\% dengan asumsi variabel lain dianggap konstan.

\section{Hasil Uji Hipotesis}

\section{a. Hasil Uji t}

Uji t bertujuan untuk mengetahui apakah variabel bebas (independen) secara parsial atau individu mempunyai pengaruh terhadap variabel terikat (dependen) dan untuk mengetahui seberapa jauh pengaruh variabel independen secara individual dalam menerangkan variasi variabel dependen. Uji t dalam penelitian ini diukur dengan menggunakan taraf signifikansi sebesar 0,05 atau $5 \%$ yaitu jika signifikansi variabel independen kurang dari 0,05 maka terdapat pengaruh yang signifikan, tetapi apabila signifikansi variabel independen lebih dari 0,05 maka pengaruh tidak signifikan dan melihat nilai $t$ pada setiap variabel indpenden atau variabel bebas. Pengujian hipotesis $t$ ini dilakukan dengan menentukan dan terlebih dahulu. Dimana adalah hipotesis yang menyatakan tidak adanya pengaruh antara dua variabel atau lebih dan adalah hipotesis yang menyatakan adanya hubungan antara variabel satu dengan yang lain. Hasil uji t dalam penelitian ini adalah sebagai berikut:

Tabel IV.6. Hasil Uji t

\begin{tabular}{|c|c|c|c|c|c|c|}
\hline \multicolumn{7}{|c|}{ Coefficients $^{\mathrm{a}}$} \\
\hline & \multirow[t]{2}{*}{ Model } & \multicolumn{2}{|c|}{$\begin{array}{l}\text { Unstandardized } \\
\text { Coefficients }\end{array}$} & \multirow{2}{*}{$\begin{array}{c}\text { Standardize } \\
\mathrm{d} \\
\text { Coefficients } \\
\text { Beta }\end{array}$} & \multirow[t]{2}{*}{$\mathrm{t}$} & \multirow[t]{2}{*}{ Sig. } \\
\hline & & B & Std. Error & & & \\
\hline \multirow{3}{*}{1} & (Constant) & 1,024 & ,539 & & 1,900 & ,061 \\
\hline & NDTS & 2,038 & 1,455 & ,157 & 1,401 &, 165 \\
\hline & COFD &, 529 & ,301 & , 197 & 1,756 & ,083 \\
\hline
\end{tabular}

Sumber: Hasil Output Olah Data SPSS 24

Dari hasil uji t tersebut, maka diperoleh interprestasi sebagai berikut:

1) Pengaruh Variabel non debt tax sheild $\left(\mathrm{X}_{1}\right)$ Terhadap Struktur Modal (Y).

Berdasarkan tabel IV.8 diperoleh hasil t-hitung sebesar 1,401 dan nilai Sig.t. diperoleh sebesar 0, $165>0,05$, maka Ho diterima dan $\mathrm{H}_{1}$ ditolak yang berarti tidak terdapat pengaruh positif non debt 
tax sheild terhadap struktur modal pada perusahaan manufaktur sub sektor logam dan sejenisnya yang terdaftar di Bursa Efek Indonesia (BEI)

2) Pengaruh Variabel Cost of financial distress $\left(\mathrm{X}_{2}\right)$ Terhadap Struktur Modal (Y).

Berdasarkan tabel IV.9 diperoleh hasil t-hitung sebesar 1,756 dan nilai Sig.t. diperoleh sebesar 0, $083>0,05$, maka Ho diterima dan $\mathrm{H}_{1}$ ditolak yang berarti tidak terdapat pengaruh positif cost of financial distress terhadap struktur modal pada perusahaan sub sektor logam dan sejenisnya yang terdaftar di Bursa Efek Indonesia (BEI).

\section{b. Hasil Uji F}

Dari hasil Uji F untuk menjelaskan hipotesis secara simultan dapat dilihat pada Tabel IV.10 dibawah ini:

Tabel IV.7 Hasil Uji F

\begin{tabular}{|c|l|l|l|l|c|c|}
\hline \multicolumn{7}{|c|}{ ANOVA $^{\mathbf{a}}$} \\
\hline \multicolumn{2}{|c|}{ Model } & $\begin{array}{c}\text { Sum of } \\
\text { Squares }\end{array}$ & df & $\begin{array}{c}\text { Mean } \\
\text { Square }\end{array}$ & F & Sig. \\
\hline \multirow{3}{*}{1} & Regression & 19,848 & 2 & 9,924 & 2,295 &, $108^{\text {b }}$ \\
\cline { 2 - 8 } & Residual & 328,624 & 76 & 4,324 & & \\
\cline { 2 - 8 } & Total & 348,471 & 78 & & & \\
\hline
\end{tabular}

a. Dependent Variable: Struktur_Modal

b. Predictors: (Constant), COFD, NDTS

Sumber: Hasil Olah Data SPSS 24

Berdasarkan table IV.7 hasil uji $F$ di dapat dengan nilai $F_{\text {hitung }}$ sebesar 2,295 dengan tingkat Sig. 0, 108, karena nilai Sig. F > 0,05, maka Ho diterima dan $\mathrm{H}_{1}$ ditolak. Hal ini berarti tidak terdapat pengaruh variabel non debt tax shield $\left(\mathrm{X}_{1}\right)$ dan cost of financial distress $\left(\mathrm{X}_{2}\right)$ terhadap struktur modal (Y) pada perusahaan sub sektor logam dan sejenisnya yang terdaftar di Bursa Efek Indonesia (BEI)

\section{c. Hasil Uji Koefisien Korelasi (R)}

Hasil perhitungan koefisien korelasi dapat dilihat pada tabel IV.8. dibawah ini:

Tabel IV.8 Hasil Uji Koefisien Korelasi (R)

\begin{tabular}{|c|c|c|c|c|}
\hline \multicolumn{7}{|c|}{ Model Summary $^{\text {b }}$} \\
\hline Model & $\mathrm{R}$ & R Square & $\begin{array}{c}\text { Adjusted R } \\
\text { Square }\end{array}$ & $\begin{array}{c}\text { Std. Error of } \\
\text { the Estimate }\end{array}$ \\
\hline 1 &, $239^{\mathrm{a}}$ &, 057 &, 032 & 2,07942 \\
\hline $\begin{array}{l}\text { a. Predictors: (Constant), COFD, NDTS } \\
\text { b. Dependent Variable: Struktur_Modal } \\
\text { Sumber: Hasil Olah Data SPSS 24 }\end{array}$ \\
\hline
\end{tabular}

Berdasarkan nilai koefisien korelasi (R) pada tabel diatas sebesar 0. 239 atau sebesar 23,9\% yang berarti hubungan antara $\mathrm{R}^{2}$ variabel non debt tax shield $\left(\mathrm{X}_{1}\right)$ dan cost of financial distress $\left(\mathrm{X}_{2}\right)$ terhadap struktur modal (Y) memiliki hubungan yang sangat lemah, sedangkan sisanya $76,1 \%$ terdapat pada faktor-faktor lain diluar penelitian ini.

\section{d. Hasil Uji Koefisien Determinasi (Uji $\mathbf{R}^{2}$ )}

Hasil perhitungan koefisien korelasi dapat dilihat pada tabel IV.9. dibawah ini: 
Tabel IV.9.Hasil Uji Koefisien Determinasi $\left(\mathbf{R}^{2}\right)$

\begin{tabular}{|c|c|c|c|c|}
\hline \multicolumn{5}{|c|}{ Model Summary $^{\mathbf{b}}$} \\
\hline Model & $\mathrm{R}$ & $\mathrm{R}$ Square & $\begin{array}{c}\text { Adjusted R } \\
\text { Square }\end{array}$ & $\begin{array}{c}\text { Std. Error of } \\
\text { the Estimate }\end{array}$ \\
\hline 1 &, $239^{\mathrm{a}}$ &, 057 &, 032 & 2,07942 \\
\hline
\end{tabular}

Hasil koefisien determinasi (R2) pada Tabel IV.9 diperoleh nilai sebesar 0,057 atau sebesar $5,7 \%$. Hal ini berarti variasi dalam struktur modal $(\mathrm{Y})$ dijelaskan oleh variabel non debt tax shield $\left(\mathrm{X}_{1}\right)$ dan cost of financial distress $\left(\mathrm{X}_{2}\right)$ sebesar 5,7\% dan sisanya sebesar 94,3\% dijelaskan oleh faktorfaktor lain diluar penelitian ini.

\section{Pembahasan}

Penelitian ini bertujuan untuk mengetahui pengaruh non debt tax sheild dan cost of financial distress terhadap struktur modal pada perusahaan manufaktur sub sektor logam dan sejenisnya yang terdaftar di Bursa Efek Indonesia (BEI) tahun 2013-2017. Dari hasil olah data dan analisis data yang telah dilakukan, maka didapat pembahasannya adalah sebagai berikut :

1. Pengaruh non debt tax sheild $\left(\mathrm{X}_{1}\right)$ terhadap struktur modal (Y) pada perusahaan sub sektor logam dan sejenisnya yang terdaftar di Bursa Efek Indonesia (BEI).

Berdasarkan hasil analisis statistik yang telah dilakukan untuk variabel non debt tax sheild dapat disimpulkan bahwa variabel non debt tax sheild tidak berpengaruh terhadap struktur modal pada perusahaan sub sektor logam dan sejenisnya yang terdaftar di Bursa Efek Indonesia (BEI). Hal ini terlihat dari nilai signifikansi t yang lebih besar dari standar signifikansi $\alpha=5 \%$ yaitu dengan diperoleh hasil t-hitung sebesar 1,401 dan nilai signifikansi t diperoleh sebesar 0,165>0,05, maka Ho diterima dan H1 ditolak.

Disamping itu, Menurut Suripto (2015: 8) dalam kajiannya mengemukakan bahwa: "Struktur modal perusahaan ditentukan oleh karakteristik spesifik perusahaan antara lain fixed assets, size of firm, non debt tax shield dan profitability. Perlindungan pajak melalui Non Debt Tax Shield akan memberikan insentif yang kuat terhadap utang. Manfaat pajak dari utang menurun ketika pengurangan pajak yang lain, seperti kenaikan penyusutan."

Penelitian ini mendukung penelitian yang dilakukan oleh (Erma dan Yad, 2015), (Cortez dan Susanto, 2012), (Liem det al., 2013), (Masidonda et al. 2013), (Rasoolpur, 2012), dan (Muhammadinah, 2017) menyatakan bahwa variabel non-debt tax shield tidak memiliki pengaruh terhadap struktur modal.

2. Pengaruh cost of financial distress $\left(\mathbf{X}_{2}\right)$ terhadap struktur modal $(\mathbf{Y})$ pada perusahaan sub sektor logam dan sejenisnya yang terdaftar di Bursa Efek Indonesia (BEI).

Berdasarkan hasil analisis statistik yang telah dilakukan untuk variabel cost of financial distress dapat disimpulkan bahwa variabel cost of financial distress tidak berpengaruh terhadap struktur modal pada perusahaan sub sektor logam dan sejenisnya yang terdaftar di Bursa Efek Indonesia (BEI). Hal ini terlihat dari nilai signifikansi t yang lebih besar dari standar signifikansi $\alpha=5 \%$ yaitu dengan diperoleh hasil t-hitung sebesar 1,756 dan nilai signifikansi t diperoleh sebesar 0, $083>0,05$, maka Ho diterima dan $\mathrm{H}_{1}$ ditolak.

Berdasarkan trade off theory, semakin tinggi kemungkinan financial distress, akan semakin tinggi pula kemungkinan financial distress costs yang harus ditanggung oleh perusahaan. Hal ini akan menyebabkan tingkat penggunaan hutang yang optimum semakin rendah, sehingga perusahaan seharusnya menggunakan lebih sedikit hutang.

Selain itu, semakin tinggi risiko bisnis, maka kemungkinan terjadinya financial distress (kesulitan keuangan) juga semakin tinggi ketika perusahaan menggunakan banyak hutang (Krishnan dan Moyers dalam Indrajaya, Herlina dan Setiadi, 2011). Hal tersebut dikarenakan earning yang tidak 
menentu akan menyebabkan arus kas masuk yang tidak menentu pula. Jika perusahaan rugi atau arus kas yang masuk tidak mencukupi untuk membayar beban bunga, maka perusahaan dapat bangkrut.

Hasil penelitian ini mendukung penelitian yang dilakukan oleh (Handayani, 2011), (Tarazi, 2013), dan (Muhammadinah, 2017) menunjukkan bahwa cost of financial distress tidak berpengaruh secara signifikan terhadap Struktur Modal.

3. Pengaruh non debt tax sheild $\left(\mathrm{X}_{1}\right)$ dan cost of financial distress $\left(\mathrm{X}_{2}\right)$ terhadap struktur modal (Y) pada perusahaan sub sektor logam dan sejenisnya yang terdaftar di Bursa Efek Indonesia (BEI).

Berdasarkan hasil analisis statistik yang telah dilakukan untuk variabel non debt tax sheild dan cost of financial distress terhadap struktur modal dapat disimpulkan bahwa variabel non debt tax sheild $\left(\mathrm{X}_{1}\right)$ dan cost of financial distress $\left(\mathrm{X}_{2}\right)$ tidak berpengaruh terhadap struktur modal $(\mathrm{Y})$ pada perusahaan sub sektor logam dan sejenisnya yang terdaftar di Bursa Efek Indonesia (BEI).

Hal ini ditunjukkan dengan nilai signifikansi F yang lebih besar dari standar signifikansi $\alpha=5 \%$.

Nilai koefisien korelasi (R) pada tabel IV.8 sebesar 0,239 yang berarti hubungan antara $\mathrm{R}^{2}$ variabel non debt tax sheild $\left(\mathrm{X}_{1}\right)$ dan cost of financial distress $\left(\mathrm{X}_{2}\right)$ terhadap struktur modal (Y) memiliki hubungan yang lemah yaitu sebesar 0,239 atau 23,9\%.

Hasil koefisien determinasi $\left(\mathrm{R}^{2}\right)$ pada tabel IV.9 diperoleh nilai sebesar 0,057 atau sebesar 5,7\%. Hal ini berarti variasi dalam struktur modal $(\mathrm{Y})$ dijelaskan oleh variabel non debt tax sheild $\left(\mathrm{X}_{1}\right)$ dan cost of financial distress $\left(\mathrm{X}_{2}\right)$ sebesar 5,7\% dan sisanya sebesar 94,3\% dijelaskan oleh faktor-faktor lain diluar penelitian ini.

Hasil penelitian ini mendukung penelitian yang dilakukan oleh (Muhammadinah, 2017) menunjukkan bahwa variabel non debt tax sheild $\left(\mathrm{X}_{1}\right)$ dan cost of financial distress $\left(\mathrm{X}_{2}\right)$ terhadap struktur modal (Y) tidak berpengaruh secara signifikan terhadap Struktur Modal dan memiliki hubungan yang sangat lemah dibandingkan dengan faktor-faktor lain diluar penelitian ini.

\section{KESIMPULAN DAN SARAN}

\section{Kesimpulan}

Sesuai dengan analisis data, pembahasan yang telah dipaparkan pada Bab sebelumnya, maka ditarik kesimpulan sebagai berikut:

1. Variabel non-debt tax shield (X1) secara parsial tidak berpengaruh terhadap struktur modal (Y) perusahaan sub sektor logam dan sejenisnya yang terdaftar di Bursa Efek Indonesia (BEI). Hal ini dapat ditunjukan dengan hasil uji t yang diperoleh $t_{\text {-hitung }}$ sebesar 1,401 dan nilai Sig.t. diperoleh sebesar 0,165 $>0,05$, maka Ho diterima dan $\mathrm{H}_{1}$ ditolak

2. Variabel cost of financial distress (X2) secara parsial tidak berpengaruh terhadap struktur modal (Y) perusahaan sub sektor logam dan sejenisnya yang terdaftar di Bursa Efek Indonesia (BEI). Hal ini dapat ditunjukan dengan hasil uji t yang diperoleh $\mathrm{t}_{\text {-hitung }}$ sebesar 1,756 dan nilai Sig.t. diperoleh sebesar 0,083 $>0,05$, maka Ho diterima dan $\mathrm{H}_{1}$ ditolak

3. Variabel non-debt tax shield $\left(\mathrm{X}_{1}\right)$ dan cost of financial distress $\left(\mathrm{X}_{2}\right)$ secara simultan tidak berpengaruh terhadap struktur modal (Y) pada perusahaan sub sektor logam dan sejenisnya yang terdaftar di Bursa Efek Indonesia (BEI). Hal ini dapat ditunjukan dengan hasil uji $\mathrm{F}$ yang diperoleh nilai $\mathrm{F}_{\text {hitung }}$ sebesar 2,295 dengan tingkat Sig.F sebesar 0,108, karena nilai Sig. F > 0,05, maka Ho diterima dan $\mathrm{H}_{1}$ ditolak.

\section{Saran}

Berdasarkan kesimpulan hasil penelitian diatas, maka pada bagian berikut perlu diberikan saran-saran sebagai berikut:

1. Bagi perusahaan penting untuk memperhatikan variabel-variabel yang dapat mempengaruhi struktur modal, khusunya variabel non debt tax sheild dan cost of financial distress karena variabel tersebut terbukti tidak pengaruh terhadap struktur modal, sehingga diharapkan mampu menciptakan struktur modal yang optimal.

2. Bagi manajer keuangan penting untuk mempertimbnagkan analisis subyektif (judgment) serta mengetahui teori-teori yang berkaitan pada penentuan struktur modal

3. Penelitian berikutnya diharapkan menggunakan variabel lainnya, yang belum dimasukkan dalam model penelitian ini karena variabel dalam penelitian ini terdapat hubungan korelasi yang sangat lemah terhadap struktur modal seperti struktur likuiditas, profitabilitas, pertumbuhan perusahaan dan aktiva berwujud. 


\section{DAFTAR PUSTAKA}

\section{Buku:}

Djumahi. 2015. Effect of Compensation on Motivation, Organizational Commitment and Employee Performance

Efferin, Sujoko dkk. 2008. Metode Penelitian Akuntansi: Mengungkap Fenomena dengan pendekatan Kuantitatif dan Kualitatif, GRAHA ILMU, Yogyakarta

Ghozali, Imam. 2009. Aplikasi Analisis Multivariate dengan Program SPSS. Edisi Keempat, Semarang: Universitas Diongoro

Ghozali, Imam. 2013. Aplikasi Analisis Multivariate dengan Program IBM SPSS 21 Update PLS Regresi. Semarang: Badan Penerbit Universitas Diponegoro

Ghozali, Imam. 2016. Aplikasi Analisis Multivariete Dengan Program IBM SPSS 23 (Edisi 8). Cetakan ke VIII. Semarang : Badan Penerbit Universitas Diponegoro.

Kasmir. 2013. Analisis Laporan Keuangan. Edisi Pertama. Cetakan Keempat. Jakarta: Rajawali Pers

Kuncoro. 2012. Metode Riset Untuk Bisnis \& Ekonomi: Bagaimana Meneliti dan Menulis Tesis. Jakarta: Erlangga.

Ross, Stephen A, Randolph W. Westerfield dan Jeffrey Jeff. 2013. Corporate Finance Tenth Edition. New York : McGraw-Hill

Sukardi. 2009. Metodologi Penelitian Pendidikan(Kompetensi dan Praktiknya). Jakarta: Bumi Aksara.

Sugiyono. 2010. Metode Penelitian Pendidikan Pendekatan Kuantitatif, kualitatif, dan R\&D. Bandung: Alfabeta

Sugiyono. 2014. Metode Penelitian Pendidikan Pendekatan Kuantitatif, Kualitatif Dan R\&D. Bandung: Alfabeta

Sugiyono. 2015. Metode Penelitian Kombinasi (Mix Methods). Bandung: Alfabeta.

\section{Laporan Penelitian dan Jurnal:}

Bayrakdaroglu, Ali.,IlhanEge., and Nusret Yazici. 2013. A Panel Data Analysis of Capital Structure Determinants: Empirical Results from Turkish Capital Market. International Journal of Economics and Finance. 5 (4), pp: 131- 140.

Beaver, W. H. et al. 2010. "Financial Statement Analisis and the Prediction of Financial Distress". Foundations and Trends in Accounting. Vol. 5, No.2. pp. 99173.

Cortez Michael Angelo and Stevie Susanto. 2012.The Determinants Of Corporate Capital Structure : Evidence From Japanese Manufacturing Companies. Journal of International Business Research, 11 (3): h: 121-133: Special Issue.

Cristie, Yanuar dan Fuad. 2015. Analisis Faktor-Faktor Yang Mempengaruhi Struktur Modal, Dengan Ukuran Perusahaan Sebagai Variabel Moderating (Studi Empiris Pada Perusahaan Property And Real Estate Yang Terdaftar Di Bursa Efek Indonesia Untuk Tahun 2010-2013). Diponegoro Journal of Accounting. Volume 4, Nomor 2, Tahun 2015.

DeAngelo, Harry, and Ronald W.M. 2011. "Optimal Capital Structure Under Corporate And Personal Taxation". Journal of Financial Economics. Vol. 8, hal 3-29.

Erma dan Yadnya. 2015. Pengaruh Profitabilitas dan Struktur Kepemilikan Terhadap Kebijakan Dividen dan Nilai Perusahaan. Fakultas Ekonomi dan Bisnis Universitas Udayana, Bali.

Hasbullah, Abdul Malik Rizal. 2014. Pengaruh Profitabilitas, Likuiditas Dan Non Debt Tax Shield Terhadap Struktur Modal Pada Perusahaan Telekomunikasi Yang Terdaftar Di BEI Periode 2008 - 2012. eProceedings of Management Vol 1, No 3 Tahun 2014

Liem dkk. 2013. Faktor-Faktor Yang Mempengaruhi Struktur Modal Pada Industri Consumer Good Yang Terdaftar di BEI Periode 2007-2011. Jurnal Ilmiah Mahasiswa Universitas Surabaya, 2 (1), pp: 111.

Masidonda, Jaelani, La., MS, Idrus., Ubud, Salim., dan Djumahir. 2013. Determinants of Capital Structure and Impact Capital Structure on Firm Value. IOSR Journal of Business and Management. Vol 7 (3): Hal.23-30.

Masnoon, Maryam., dan Abiha, Saeed. 2014. Capital Structure Determinants Of Kse Listed Automobile Companies. European Scientific Journal. Vol 10 (13): Hal.451-461

Muhammadinah. 2017. Pengaruh Cost Of Financial Distress, Dan Non-Debt Tax Shield Terhadap Struktur Modal Perusahaan Sub Sektor Otomotif Yang Terdaftar Di Bursa Efek Indonesia Tahun 20142016. Jurnal I-Finance Vol.1. No 1. Juli 2017. 
Nurita, Dea. 2012. "Analisis Pengaruh, Profitabilitas, Firm Size, Non Debt Tax Shield, Deviden Payout Ratio dan Likuiditas Terhadap Struktur Modal,". Skripsi Tidak Dipublikasikan. Universitas Diponegoro

Prabansari, Yuke dan Hadri Kusuma. 2005. Faktor-faktor yang mempengaruhi struktur modal pada perusahaan manufaktur Go public yang terdapat di Bursa Efek Jakarta sinergi, Edisi khusus On finance : hlm 1-15

Putu Hary Krisnanda dan I Gusti Bagus Wiksuana. 2015. Pengaruh Ukuran Perusahaan, Pertumbuhan Penjualan dan Non-debt Tax Shield Terhadap Struktur Modal. E-Jurnal Manajemen Unud, Vol. 4, No. 5, 2015: 1434- 1451)

Rasoolpur, Gurnam, Singh. 2012. An Empirical Analysis Of Capital Structure Determinants: Evidence From The Indian Corporate Sector. International Journal of Management \& Information Technology. Vol 1 (3): Hal.1-12.

Seftianne dan Ratih Handayani. 2011. "Faktor - Faktor yang Mempengaruhi Struktur Modal pada Perusahaan Publik Sektor Manufaktur". Jurnal Bisnis dan Akuntansi, Vol. 13, No. 1, April 2011, Hlm. 39 - 56.

Tarazi, R., E., N. 2013. Determinants of Capital Structure: Evidence from Thailand Panel Data. Proceedings of 3rd Global Accounting, Finance and Economics Conference 5 - 7 May, 2013, Rydges Melbourne, Australia, ISBN: 978-1-92206923-8

Wildani, Anastasia Rizka. 2012. Pengaruh Perubahan Tarif Pajak Penghasilan Wajib Pajak Badan dan Karakteristik Perusahaan Terhadap Struktur Modal Pada Perusahaan Listing di BEI Periode 20062010. Skripsi. Universitas Indonesia

\section{Peraturan:}

Undang-Undang Nomor 36 Tahun 2008 Tentang Pajak Penghasilan (PPh)

\section{Situs/Web:}

https://finance.detik.com/berita-ekonomi-bisnis/d-3278293/ekonom-bank-dunia-ini-ungkap-turunnya-gairahmanufaktur-ri? ga=2.230906079.1375681353.1561629666-1880902114.1560765405

https://www.idx.co.id/perusahaan-tercatat/laporan-keuangan-dan-tahunan/

https://www.sahamok.com/emiten/sektor-industri-dasar-dan-kimia/sub-sektor-logam-sejenisnya/

http://sahamidx.com/

https://databoks.katadata.co.id/datapublish/2017/01/20/investasi-amerika-di-indonesia-menurun-sejak-2013

www.investor.co.id 